\title{
Olive Seed Germination and Initial Seedling Vigor as Influenced by Stratification Treatment and the Female Parent
}

\author{
Ana Morales-Sillero1, María Paz Suárez, María Rocío Jiménez, \\ Laura Casanova, José Ordovás, and Pilar Rallo \\ Departamento de Ciencias Agroforestales, ETSIA, Universidad de Sevilla, \\ Carretera de Utrera, km 1, 41013 Sevilla, Spain
}

Additional index words. Olea europaea, table olive cultivars, breeding program, seed emergence, seedling growth

\begin{abstract}
The germination of seeds and the growth of the generated plant are two phases of great importance in an olive breeding program. In this work, three stratification treatments and five cultivars (Hojiblanca, Manzanilla Cacereña, Manzanilla de Sevilla, Toffahi, and Uovo di Piccione) used as female parents in a breeding program for table olive were evaluated along two years to improve germination protocols. The stratification treatments affected seed germination (percent seeds with radicle), radicle length, seedling emergence (percent emerged hypocotyls), and the average time of emergence. The cultivars have shown great variability with respect to the requirements of the seeds and seedling growth performance. None of the treatments with heat application $\left(25^{\circ} \mathrm{C}\right)$ after chill $\left(14^{\circ} \mathrm{C}\right)$ improved the percentage of germinated seeds and seedling emergence in any year compared with the control treatment $\left(30\right.$ days at $\left.14^{\circ} \mathrm{C}\right)$. Cultivars such as Manzanilla de Sevilla and Toffahi seem to be a good choice of female progenitors to improve emergence rates and to obtain early vigorous progenies, a character that has been related to a shorter juvenile period of the seedlings. Moreover, in these progenies, a clear lower apical dominance was found from the first stages of seedling growth. The olive fruit and seed traits were also influenced by the female parent. In fact, 'Hojiblanca' and 'Uovo di Piccione' showed a higher number of empty seed fruits and double seed fruits compared with the other studied cultivars.
\end{abstract}

Seed germination and initial seedling growth are two important phases in classical plant breeding programs based on crosses between existing cultivars such as in olive species (Olea europaea L.). Olive seed germination is slow, long-lasting (even up to three years from sowing), and staggered (Lagarda et al., 1983; Sotomayor-León and Caballero, 1990). Possible reasons include both the existence of dormancy and the influence of the parents, among other factors, and these must be taken into account in a breeding program.

Olive seeds show several types of dormancy with mechanical and embryo dormancy being

\footnotetext{
Received for publication 27 July 2012. Accepted for publication 7 Oct. 2012.

This research was supported by Project AGL200765184-C02-02/AGR of the Spanish Ministry of Science and Technology (MICCIN, Ministerio de Ciencia y Tecnología) and the European Union FEDER funds.

We thank our colleague Dr. Carmen del Río, who regretfully passed away, for supplying olive fruits from the World Olive Germplasm Bank (WOGB) at IFAPA (Andalusian Institute for Research and Training in Agriculture) Córdoba. We also thank Manolo Hinojosa, Paloma Inmaculada Moreno, and Alejandro Gómez for technical assistance.

${ }^{1}$ To whom reprint requests should be addressed; e-mail amorales@us.es.
}

the most important (Alvarado, 1994). Mechanical dormancy is related to the presence of the woody endocarp, which prevents the expansion of the embryo (Crisosto and Sutter, 1985; Hartmann et al., 2010). Even after removal of the endocarp, olive seed germination under suitable conditions is slow and erratic, indicating the existence of endogenous dormancy within the embryo (Voyiatzis, 1995).

Temperature seems to be the most important factor to release embryo dormancy in the olive as in other species (García-Gusano et al., 2004; Hartmann et al., 2010; Sharma and Singh, 1978). It affects the total percentage of germination as well as the speed of the process. Different authors proposed cold stratification in wet conditions to eliminate this type of dormancy (Crisosto and Sutter, 1985; Istanbouli, 1981; Lagarda et al., 1983). Alvarado (1994) and Santos-Antunes (1999) suggested stratification at $14{ }^{\circ} \mathrm{C}$, always in darkness and during a variable time period, depending on the cultivar, although the time should not typically exceed 6 weeks. The standard protocol used in olive breeding programs in Spain reduces the time of seed stratification to $30 \mathrm{~d}$ (El Ryachi, 2007; Rallo et al., 2008). Nevertheless, El Ryachi (2007) did not find any differences when the time was reduced to $20 \mathrm{~d}$. Later, Adakalic et al. (2008) indicated that cold stratification could be reduced from 30 to $18 \mathrm{~d}$ followed by a change in temperature to $25^{\circ} \mathrm{C}$ for $12 \mathrm{~d}$, which improves the growth of the radicle. Earlier studies by Voyiatzis and Porlingis (1987) also suggested that a change in the temperature during the stratification time improves olive seed germination. These data suggest the possibility to further reduce the time of stratification and improve the protocol in olive breeding programs, although adjusted according to the parent cultivars.

Limited references are concerned with the influence of the parents on olive seed traits, seed germination, and seedling emergence and growth. Cuevas and Oller (2002) and Farinelli et al. (2008) found that both the female parent and the pollinator had some influence on the number of fruits with double and empty seeds. Bini and Benilli (1975) and Santos-Antunes (1999) observed that the germination ability depends first on the female parent and to a lesser extent on the pollinator. The importance of the female parent was underlined later by Adakalic (2003). Santos-Antunes et al. (2005) observed that the length of the juvenile period of the seedlings was also influenced by the female parent. Furthermore, a seedling's juvenile period length was correlated with the unproductive period of adult trees. Recently, Hammami et al. (2011) have shown the influence of the parents on the vigor and the growth habit of seedlings from different progenies obtained in an olive breeding program.

The aim of this work is to study the effect of different stratification treatments and table olive cultivars used as female parents on seed traits, seed germination, and early seedling growth. The results may not only help to advance knowledge of the olive species but also be of great interest in answering important questions arising in olive breeding programs such as the choice of parents, how to improve seed germination procedures, and seedling initial vigor, which is related to the length of the juvenile period. This is particularly interesting for table olive for which, although new cultivars adapted to new cropping systems demands (mechanized harvesting, irrigation expansion, susceptibility to pests and diseases, increasing demand for quality of consumer and industry, etc.) are necessary, there still is almost no information of the performance of present cultivars in breeding programs.

\section{Materials and Methods}

Plant material. Fruit samples from five open-pollinated table olive cultivars (Hojiblanca, Manzanilla Cacereña, Manzanilla de Sevilla, Toffahi, and Uovo di Piccione) were collected during the fall of 2008 and 2009 in the World Olive Germplasm Bank at IFAPA (Andalusian Institute for Research and Training in Agriculture) Córdoba in southern Spain (lat. $37^{\circ} 51^{\prime} \mathrm{N}$, long. $04^{\circ} 48^{\prime} \mathrm{W}$, altitude $117 \mathrm{~m}$ ). The fruits were randomly picked from one to three trees per cultivar on specific dates (5 Nov. 2008 and 15 Oct. 2009) once 
maturity index (Beltrán et al., 2008) was above 3 to be sure that seeds were mature and able to germinate. The seeds were obtained from the sampled fruits by removing the pulp and carefully opening the endocarp with a tube cutter.

Experimental design and measurements. The experiment was set up as a factorial design with three factors, five cultivars, three stratification treatments, and two years. They were arranged in three replications with 35 seeds per replication.

Stratification treatments were applied, each year, $4 \mathrm{~d}$ after harvest. In 2008, the treatments were: 1) control, stratification for $30 \mathrm{~d}$ at $14{ }^{\circ} \mathrm{C}$ [according to Alvarado (1994) and Santos-Antunes (1999)]; 2) T1, stratification for $18 \mathrm{~d}$ at $14{ }^{\circ} \mathrm{C}$ and $12 \mathrm{~d}$ at $25^{\circ} \mathrm{C}$ (according to Adakalic, 2003); and 3) T2, stratification for $14 \mathrm{~d}$ at $14{ }^{\circ} \mathrm{C}$ and $7 \mathrm{~d}$ at $25^{\circ} \mathrm{C}$. In 2009 , the control and $\mathrm{T} 1$ treatments were performed the same way. Considering results from 2008, T2 treatment was slightly modified by increasing stratification time at $14{ }^{\circ} \mathrm{C}$ from 14 to $18 \mathrm{~d}$, after which the seeds were again stratified for $7 \mathrm{~d}$ at $25^{\circ} \mathrm{C}$. In 2008 'Hojiblanca' trees had very low fruit load so the number of fruits sampled for this cultivar was lower than for the others. Thus, only two treatments (C and T1) and 30 seeds per replication were considered for this cultivar in that particular year.

Before the stratification treatments were applied, the numbers of parthenocarpic fruits (no seeds), fruits with empty seeds, and fruits with double seeds were determined. Empty seeds were discarded from the experiment.

After soaking the seeds in a Ziram fungicide solution $\left(2 \mathrm{~g} \cdot \mathrm{L}^{-1}\right)$ for $5 \mathrm{~min}$, each replicate was introduced into a petri dish with humid perlite (wet to field capacity) and placed into growth chambers at 14 or $25{ }^{\circ} \mathrm{C}$, depending on the treatment, in the dark. All dishes were checked periodically for adequate moisture.

After the stratification treatment and before sowing, the number of seeds with radicle (germinated) and the length of the radicle were recorded. Next, each replicate was sown into forest trays (QP T 35, <http://www. projar.es $>$ ) containing a mixture of horticultural substrate and vermiculite (8.5:1.5), which were randomly placed in a growth chamber at 24 to $25^{\circ} \mathrm{C}$ under continuous light $(24 \mathrm{~h})$. The seedling emergence (percent emerged hypocotyls) was recorded at 3-d intervals. At the end of the emergence period, one month after sowing (once most of the new seedlings developed two to three nodes in the primary shoot), the total emergence percentage and the average time of emergence were determined. The latter was expressed as $\sum\left(D^{*} n\right) / \sum n$ according to Edmond and Drappala (1958), with $D$ representing the number of days from sowing and $n$ the number of new germinated seeds every $3 \mathrm{~d}$. The following seedling traits were also measured in the primary shoot: height, number of nodes, and number of secondary shoots.

Next, the seedlings were transplanted into square pots $(15 \times 15 \times 20 \mathrm{~cm})$ filled with a sand:corrected peat substrate at a 1:1 $\left(\mathrm{v} \cdot \mathrm{v}^{-1}\right)$ ratio. Each replicate was again randomly placed into a greenhouse and grown under forced conditions as described by SantosAntunes et al. (2005). The aforementioned seedling traits were recorded at $\approx 10$ to 11 months after sowing. The diameter of the primary shoot was determined at $0.75 \mathrm{~m}$.

Statistical analysis. The data concerning the types of fruit and seeds (parthenocarpic fruits and fruits with double and empty seeds) were analyzed with a test of comparison of proportions $(P<0.01)$. The remaining traits were subjected to analysis of variance (ANOVA; factorial ANOVA) to determine the effect of the cultivar, the stratification treatment, the year, and the interactions (cultivar * stratification, year * cultivar and year * stratification). When combined data from both years were studied, only two treatments (C and T1) were considered for ANOVA analysis, because T2 was modified from one year to another.

Tukey's test $(P<0.05)$ was used to discriminate among the mean values. When necessary, to achieve normality and homogenize the variance, data were previously transformed using the arcsine of the square root or Box-Cox power transformations (Box and Cox, 1964). Pearson correlation coefficients among all of the measured parameters were calculated. All analyses were performed using StatGraphics Plus 5.1. software.

\section{Results and Discussion}

Parthenocarpic, double-seeded, and empty seed fruits. In 2009 the percentages of fruits with empty seeds, fruits with two seeds, and parthenocarpic fruits (no seeds) increased, in general, compared with the previous year, but only in a significant way in the case of empty seed fruits (Table 1). Probably, this was a consequence of the different climatic conditions during flowering and fruit set, especially temperature, the importance of which has been indicated in previous works (Bradley et al., 1961; Orlandi et al., 2003). In fact, the mean temperature along this period (from mid-April to June) was clearly higher in 2009 (Fig. 1). Significant differences were found among the cultivars for the mentioned seed traits, in particular the number of empty seed fruits and double seed fruits. Parthenocarpic fruits were found only in 2009, except for 'Hojiblanca'. The cultivars Manzanilla Cacereña and Toffahi showed the highest although low percentages (below 3\%) of these fruits in 2009. The Hojiblanca and Uovo de Piccione cultivars always showed the highest percentages of empty seed and double seed fruits, reaching up in the case of 'Hojiblanca' to more than $30 \%$ and $35 \%$, respectively. On the contrary, 'Manzanilla Cacereña' always had the lowest percentages of both type of fruits (below 6\% and $1 \%$ of empty seed and double seed fruits, respectively). These results seem to confirm those of Cuevas and Oller (2002) and Farinelli et al. (2008), who suggested that the female parents, as well as the pollinators, may influence the proportions of fruits with empty seeds and particularly double seeds.

Seed germination and seedling emergence. Seed germination after stratification and seedling emergence after sowing were influenced by both stratification treatments and cultivars in 2008 and in 2009, and the responses were not modified by the interaction of both factors (Table 2). Except for 'Uovo di Piccione', seed germination values were lower in 2008 than in 2009, which could be partially the result of a high fungi contamination that affected $\approx 30 \%$ of the seeds (data not shown).

Because stratification in the olive is performed at a rather high temperature $\left(14{ }^{\circ} \mathrm{C}\right)$, compared with other fruit species such as peach $\left(7^{\circ} \mathrm{C}\right)$ (Martínez-Gómez and Dicenta, $2001)$ or apple $\left(5^{\circ} \mathrm{C}\right)$ (Gniazdowska et al., 2010), germinated seeds were found before sowing in all the cultivars and treatments. In some cases, further germination occurred in the greenhouse, as evidenced by a higher seedling emergence rate. For some of the cultivars and treatments, seedling emergence was lower than initial germination. Root damage during sowing may explain, at least in part, this decrease in the percentage of emergence.

None of the treatments with the application of heat after chill $\left(\mathrm{T} 1=18 \mathrm{~d}\right.$ at $14{ }^{\circ} \mathrm{C}$ and $12 \mathrm{~d}$ at $25^{\circ} \mathrm{C}$; T2 $=14 \mathrm{~d}$ at $14^{\circ} \mathrm{C}$ and $7 \mathrm{~d}$ at $25^{\circ} \mathrm{C}$ in 2008 ; and $18 \mathrm{~d}$ at $14{ }^{\circ} \mathrm{C}$ and $7 \mathrm{~d}$ at $25^{\circ} \mathrm{C}$ in 2009) improved the percentage of germinated seeds or the percentage of emerged seedlings compared with the control treatment $\left(30 \mathrm{~d}\right.$ at $\left.14{ }^{\circ} \mathrm{C}\right)$ in either year (Table 2$)$. The seed germination percentage in this treatment was $\approx 12$ and 30 points higher than in $\mathrm{T} 1$ and $\mathrm{T} 2$, respectively, in 2008 and 26 and 35 points higher in 2009. Nevertheless, the $\mathrm{T} 1$ treatment increased by $24 \mathrm{~mm}$ the radicle length as compared with both the control and T2 treatments in 2008. In 2009 it increased by $26 \mathrm{~mm}$ with respect to the control and $16 \mathrm{~mm}$ as compared with the $\mathrm{T} 2$ treatment. On the other hand, significant differences were found in the average time for seedling emergence after sowing in 2008 (Table 2), which mean value for T1 declined $\approx 5 \mathrm{~d}$ with respect to the $10 \mathrm{~d}$ of the control and T2. In 2009, however, seedling emergence was delayed up to $\approx 13 \mathrm{~d}$, and no differences between the treatments were found.

Considering the cultivars, significant differences were found for all of the studied traits in both years (Table 2). In general, the best seed germination and seedling emergence results were obtained for 'Manzanilla de Sevilla' and 'Toffahi' (up to $69 \%$ and $67 \%$, respectively, of seedling emergence in 2009). These cultivars, in particular the first one, showed high radicle length values. The Manzanilla Cacereña cultivar was also highlighted by the seed germination, radicle length, and seedling emergence, particularly in 2009. On the contrary, 'Hojiblanca' showed the lowest seed germination and seedling emergence (less than $4 \%$ and $35 \%$ 
Table 1. Percentage of parthenocarpic fruits, fruits with double seeds, and fruits with empty seeds in original fruit samples per cultivar and year.

\begin{tabular}{|c|c|c|c|c|c|c|c|c|c|c|c|c|}
\hline & \multicolumn{4}{|c|}{2008} & \multicolumn{4}{|c|}{2009} & \multicolumn{4}{|c|}{ 2008-09 } \\
\hline & $\begin{array}{c}\text { Fruit } \\
\text { number }\end{array}$ & $\begin{array}{c}\text { Parthenocarpic } \\
\text { fruits }(\%)\end{array}$ & $\begin{array}{l}\text { Empty } \\
\text { seed } \\
\text { fruits (\%) }\end{array}$ & $\begin{array}{c}\text { Double } \\
\text { seed } \\
\text { fruits }(\%)\end{array}$ & $\begin{array}{c}\text { Fruit } \\
\text { number }\end{array}$ & $\begin{array}{l}\text { Parthenocarpic } \\
\text { fruits }(\%)\end{array}$ & $\begin{array}{c}\text { Empty } \\
\text { seed } \\
\text { fruits (\%) }\end{array}$ & $\begin{array}{c}\text { Double } \\
\text { seed } \\
\text { fruits (\%) }\end{array}$ & $\begin{array}{c}\text { Fruit } \\
\text { number }\end{array}$ & $\begin{array}{l}\text { Parthenocarpic } \\
\text { fruits }(\%)\end{array}$ & $\begin{array}{l}\text { Empty } \\
\text { seed } \\
\text { fruits }(\%)\end{array}$ & $\begin{array}{c}\text { Double } \\
\text { seed } \\
\text { fruits }(\%)\end{array}$ \\
\hline Hojiblanca & 234 & 0.0 & $17.5 \mathrm{a}^{\mathrm{z}}$ & $11.1 \mathrm{a}$ & 642 & $0.0 \mathrm{c}$ & $31.6 \mathrm{a}$ & $37.9 \mathrm{a}$ & 876 & 0.0 & $24.6 \mathrm{a}$ & $24.5 \mathrm{a}$ \\
\hline $\begin{array}{l}\text { Manzanilla } \\
\text { Cacereña }\end{array}$ & 359 & 0.0 & $2.8 \mathrm{c}$ & $0.0 \mathrm{~b}$ & 628 & $2.7 \mathrm{a}$ & $5.6 \mathrm{c}$ & $0.5 \mathrm{c}$ & 987 & 1.4 & $4.2 \mathrm{~b}$ & $0.2 \mathrm{~b}$ \\
\hline $\begin{array}{l}\text { Manzanilla } \\
\text { de Sevilla }\end{array}$ & 377 & 0.0 & $12.2 \mathrm{ab}$ & $0.8 \mathrm{~b}$ & 623 & $1.3 \mathrm{ab}$ & $15.9 \mathrm{~b}$ & $1.3 \mathrm{c}$ & 1000 & 0.6 & $14.0 \mathrm{ab}$ & $1.0 \mathrm{~b}$ \\
\hline $\begin{array}{l}\text { Uovo di } \\
\text { Piccione }\end{array}$ & 315 & 0.0 & $14.3 \mathrm{ab}$ & $7.6 \mathrm{a}$ & 626 & $0.2 \mathrm{bc}$ & $35.6 \mathrm{a}$ & $11.0 \mathrm{~b}$ & 941 & 0.1 & $25.0 \mathrm{a}$ & $9.3 \mathrm{ab}$ \\
\hline \multicolumn{13}{|l|}{ Year } \\
\hline 2008 & & & & & & & & & & 0.0 & $11.3 \mathrm{~b}$ & 4.0 \\
\hline 2009 & & & & & & & & & & 1.1 & $20.7 \mathrm{a}$ & 10.5 \\
\hline
\end{tabular}

${ }^{\mathrm{z}}$ Different letters indicate significant differences in pairwise comparison according to a binomial proportion. The absence of letters means that there are not significant differences among parameters.

${ }^{y}$ Calculated among the whole data.

Ns, $*$ and $* * *$ indicate nonsignificant and significant differences at $P<0.05$ or 0.001 , respectively.

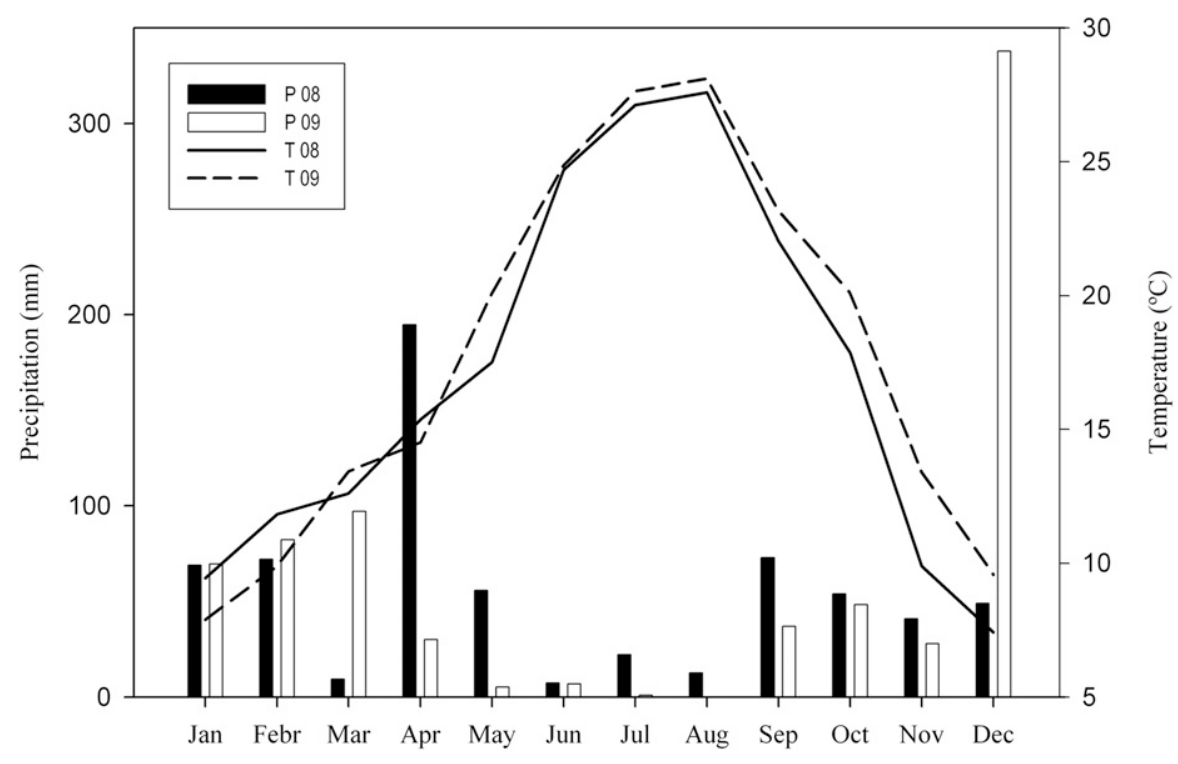

Fig. 1. Monthly rainfall (P) and mean temperature (T) of 2008 (08) and 2009 (09) in Córdoba, where fruits were sampled.

in 2008 and 2009, respectively) and low radicle length. 'Uovo di Piccione' was also highlighted by a low seedling emergence values and radicle length. The plant emergence always took place earlier in 'Manzanilla Cacereña' ( $\approx 6 \mathrm{~d}$ in 2008 and $\approx 10 \mathrm{~d}$ in 2009). In contrast, emergence was delayed $13 \mathrm{~d}$ in 'Toffahi' in 2008 and $17 \mathrm{~d}$ in 'Hojiblanca' in 2009.

When data of 2008 and 2009 were combined for the five studied cultivars and the control and T1 treatments (T2 in 2009 differed from 2008), no significant differences among years were found (Table 2). The best results of seedling emergence for 'Manzanilla de Sevilla' and 'Toffahi', among cultivars, and the worse ones for
'Uovo di Piccione' and 'Hojiblanca' seedlings were confirmed. Besides, the highest radicle length was found in the T1 treatment. There were interactions year * cultivar and year * stratification treatment with respect to the seed germination and seedling emergence and cultivar * stratification treatment and year * cultivar with respect to the radicle length. Considering the interaction year * cultivar, except for 'Uovo di Piccione', seed germination was higher in 2009 than in 2008, but this increase had different slopes depending on the cultivar (data not shown). This interaction may be explained by the fact that fruits were sampled 3 weeks later in 2008 and thus, cold temperatures could have induced the beginning of seed dormancy with different degrees among cultivars.

Results indicate that stratification for $18 \mathrm{~d}$ at $14{ }^{\circ} \mathrm{C}$ does not seem to be enough to eliminate seed dormancy in any of the studied cultivars, although the later increase of temperature from 14 to $25{ }^{\circ} \mathrm{C}$ within the treatment may positively affect the radicle length and even speed seedling emergence (Fig. 2 shows some examples). In a previous work, Adakalic et al. (2008) found that a treatment similar to $\mathrm{T} 1\left(18 \mathrm{~d}\right.$ at $14^{\circ} \mathrm{C}$ and $12 \mathrm{~d}$ at $\left.25^{\circ} \mathrm{C}\right)$ also increased the radicle length of 'Arbequina' and 'Koroneiki' seeds compared with a similar control treatment $\left(30 \mathrm{~d}\right.$ at $\left.14{ }^{\circ} \mathrm{C}\right)$, although they did not study seedling emergence. Furthermore, as mentioned at the end of this article, a high radicle length is not correlated to a greater seedling emergence. On the other hand, these results show that stratification requirements depend on the cultivars. Those cultivars characterized by low seed germination probably require a stratification period at $14{ }^{\circ} \mathrm{C}$ longer than $30 \mathrm{~d}$. Alvarado (1994) and Santos-Antunes (1999) suggested that this period could be increased up to 6 weeks depending on the cultivar. The observed differences between cultivars could be related to the different characteristics of the endocarps, the concentration of inhibitors in the endosperm or seedcoat, and the genetic nature of the embryos, as has also been suggested in almonds (García-Gusano et al., 2004). These traits should be taken into account in a table olive breeding program to ensure the generation of an appropriate number of seedlings according to the female parent.

Seedling growth. Seedling growth parameters were measured at one and 10 or 11 months after sowing, respectively (Tables 3 and 4). One month after sowing (Table 3), 'Manzanilla Cacereña', 'Toffahi', and 'Uovo di Piccione' highlighted by the highest values 


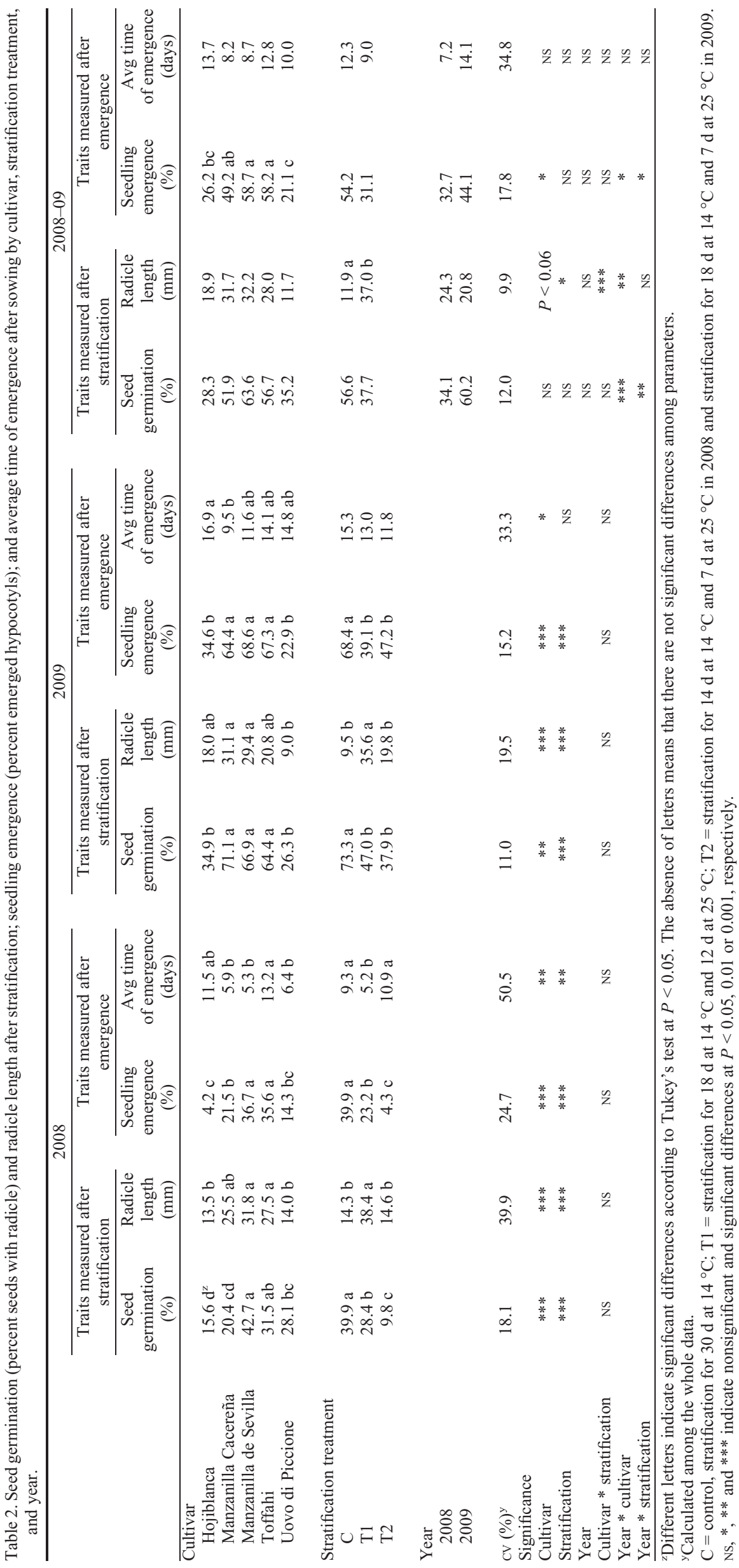

of the primary shoot height and the number of nodes in the primary shoot, although differences among cultivars were not significant in 2008. 'Toffahi' also showed the highest number of secondary shoots. In contrast, 'Hojiblanca' seedlings had always the shortest primary shoots with the lowest number of nodes and secondary shoots. Considering the stratification treatments, differences were significant only in 2008 and for the primary shoot height. In other tree species such as peaches (Martínez-Gómez and Dicenta, 2001) and almonds (Grigorian, 1972), different stratification treatments not only affected the percentage of germination, but also the growth of the seedlings at two months after sowing.

Approximately 10 months later (Table 4), significant differences were found between cultivars in either year for the mentioned parameters. The primary shoots from 'Toffahi' and 'Manzanilla de Sevilla' were always between the tallest ones (91 $\mathrm{cm}$ or greater) with the highest numbers of nodes (greater than 43) and those from 'Hojiblanca' and 'Uovo di Piccione' between the smallest ones ( $80 \mathrm{~cm}$ or less) and with the lowest number of nodes (less than 39). 'Toffahi' and to a lesser extent 'Manzanilla de Sevilla' also highlighted as the cultivars with the highest number of secondary shoots, whereas 'Manzanilla Cacereña' and 'Uovo di Piccione' were less ramified. No differences among cultivars were found for the primary shoot diameters measured at $75 \mathrm{~cm}$.

The stratification treatments did not influence seedling development in any year. Nevertheless, for the primary shoot diameter, the interaction of cultivar * stratification treatment was significant in 2009 , the diameter in the T2 seedlings being the highest ones in all cultivars except 'Toffahi', for which the control seedlings showed the highest mean values (data not shown). Besides, the interaction between cultivars and stratification treatments was also significant when combining data for all cultivars and treatments control and T1 from primary shoot height of 2008 and 2009. This was because of the better response of 'Manzanilla de Sevilla' to the T1 treatment than to the control (data not shown). The effect of the year was found only in the number of secondary shoots, which was higher in 2009 than in the previous year.

Early seedling growth is an important trait to evaluate in olive breeding programs because it has been related to future adult tree performance and particularly to the earliness of first flowering, i.e., the length of the juvenile period (De la Rosa et al., 2006; Pritsa et al., 2003; Rallo et al., 2008; SantosAntunes et al., 2005). Seedlings that grow faster in the early stages (expressed as primary shoot height and diameter) tend to overcome the juvenile period sooner, hence the importance of an adequate choice of parents. In fact, at the University of Sevilla Table Olive Breeding Program, a negative selection is systematically applied by discarding up to $40 \%$ of the shortest seedlings at 

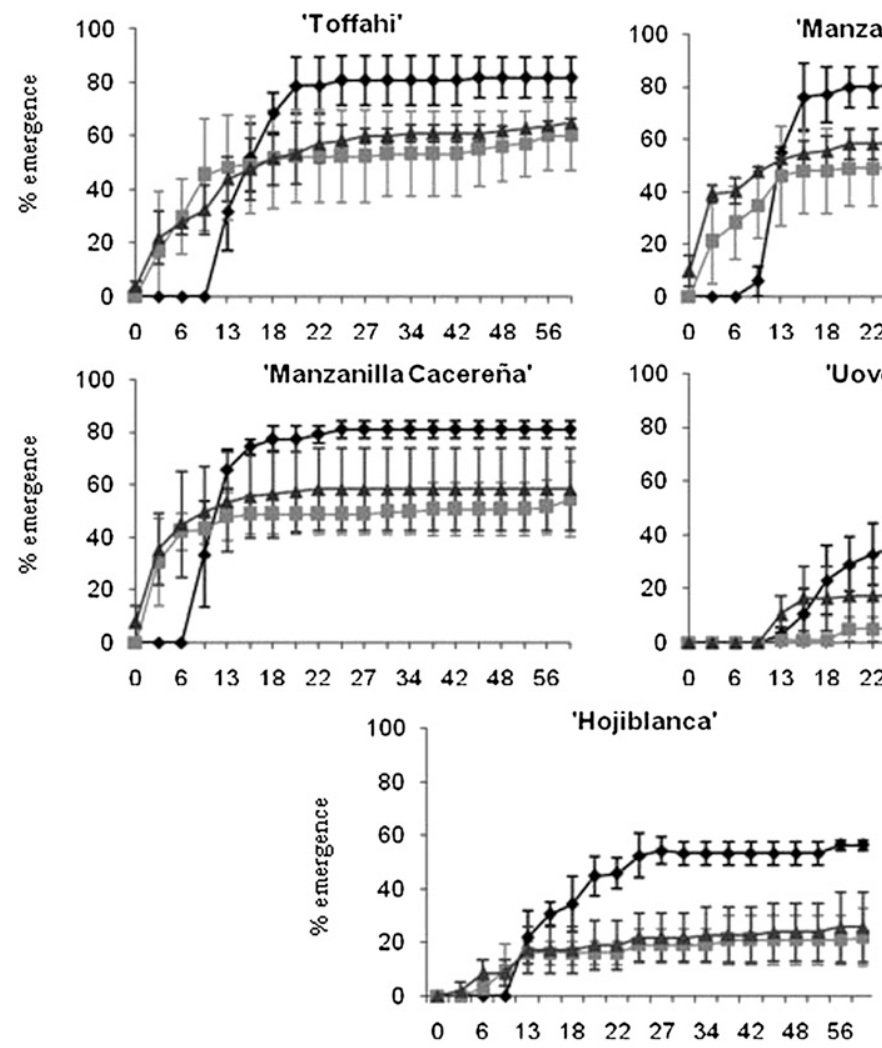

Days after sowing
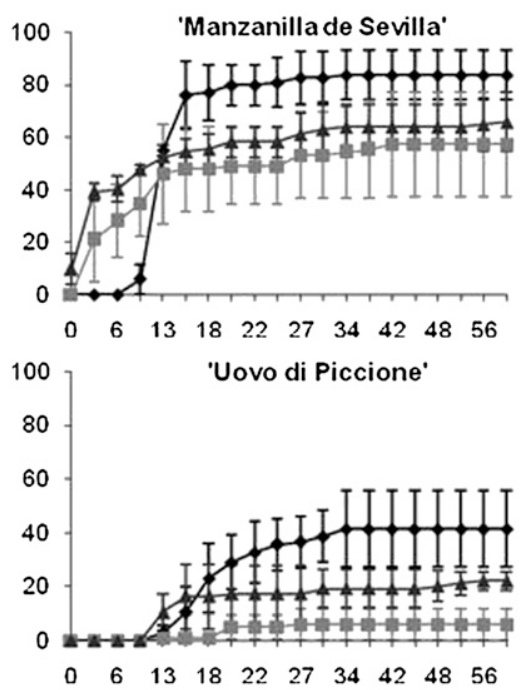

ojiblanca'

Days after sowing

$\rightarrow \mathrm{C}: 30$ days at $14^{\circ} \mathrm{C}$

\begin{abstract}
$\rightarrow-\mathrm{T} 1: 18$ days at $14^{\circ} \mathrm{C}$ and 12 days at $25^{\circ} \mathrm{C}$
\end{abstract}
$\leftarrow \mathrm{T} 2: 18$ days at $14^{\circ} \mathrm{C}$ and 7 days for $25^{\circ} \mathrm{C}$

Fig. 2. Seedling emergence evolution (\%) for the cultivars in $2009(n=3)$. The bars represent SEs for each treatment and date.

approximately nine to 15 months after sowing (Rallo et al., 2008) to reduce the number of long juvenile-period plants. We applied this selection criterion to analyze the relative percentage of discarded plants per female parent (Table 5). The discarded seedlings would be significantly higher in those cultivars characterized by a lower seedling size such as 'Hojiblanca' and 'Uovo di Piccione' (Table 4). In 'Hojiblanca', for example, $\approx 71 \%$ and $61 \%$ of the seedlings would be discarded in 2008 and 2009, respectively. According to these results, it is clear that particularly the Toffahi and Manzanilla de Sevilla cultivars are interesting progenitors to obtain faster initial seedling growth and a shorter juvenile period in the descendants.

Hammami et al. (2011) have recently suggested that an initial evaluation of seedling vigor approximately nine months after sowing may also be useful to select genotypes with interesting growth habits. In particular, a high branching habit, i.e., the number of secondary shoots, is considered to be a negative trait, and such seedlings are usually pruned in breeding programs (Hammami et al., 2011; Santos-Antunes et al., 2005). In this trial, the 'Toffahi' and 'Manzanilla de Sevilla' seedlings clearly showed the highest number of secondary shoots (Table 4), a factor to be taken into account when designing the crosses in a table olive breeding program.

We determined the correlation coefficients among all pairwise combinations of the parameters measured in the seeds and seedlings at different stages, including those

Table 3. Seedling traits one month after sowing.

\begin{tabular}{|c|c|c|c|c|c|c|c|c|c|}
\hline & \multicolumn{3}{|c|}{2008} & \multicolumn{3}{|c|}{2009} & \multicolumn{3}{|c|}{$2008-09$} \\
\hline & $\begin{array}{l}\text { Primary } \\
\text { shoot ht } \\
\text { (cm) }\end{array}$ & $\begin{array}{l}\text { Number of } \\
\text { nodes in the } \\
\text { primary shoot }\end{array}$ & $\begin{array}{l}\text { Number of } \\
\text { secondary } \\
\text { shoots }\end{array}$ & $\begin{array}{l}\text { Primary } \\
\text { shoot ht } \\
(\mathrm{cm})\end{array}$ & $\begin{array}{c}\text { Number } \\
\text { of nodes in } \\
\text { the primary shoot }\end{array}$ & $\begin{array}{l}\text { Number of } \\
\text { secondary } \\
\text { shoots }\end{array}$ & $\begin{array}{l}\text { Primary } \\
\text { shoot ht } \\
(\mathrm{cm})\end{array}$ & $\begin{array}{l}\text { Number of } \\
\text { nodes in the } \\
\text { primary shoot }\end{array}$ & $\begin{array}{c}\text { Number of } \\
\text { secondary } \\
\text { shoots }\end{array}$ \\
\hline \multicolumn{10}{|l|}{ Cultivar } \\
\hline Hojiblanca & 5.5 & 3.1 & $0.4 \mathrm{~b}$ & $5.7 \mathrm{~b}$ & $4.6 \mathrm{~b}$ & $0.8 \mathrm{~b}$ & $6.0 \mathrm{~b}$ & $4.0 \mathrm{~b}$ & $0.8 \mathrm{~b}$ \\
\hline Manzanilla Cacereña & 7.1 & 3.9 & $0.9 \mathrm{ab}$ & $8.3 \mathrm{a}$ & $6.1 \mathrm{a}$ & $0.9 \mathrm{~b}$ & $8.0 \mathrm{a}$ & $5.0 \mathrm{a}$ & $1.0 \mathrm{~b}$ \\
\hline Manzanilla de Sevilla & 6.5 & 4.1 & $0.8 \mathrm{ab}$ & $7.3 \mathrm{ab}$ & $5.7 \mathrm{ab}$ & $1.0 \mathrm{~b}$ & $6.6 \mathrm{ab}$ & $4.8 \mathrm{ab}$ & $0.9 \mathrm{~b}$ \\
\hline Toffahi & 6.6 & 4.0 & $1.9 \mathrm{a}$ & $8.4 \mathrm{a}$ & $6.1 \mathrm{a}$ & $2.8 \mathrm{a}$ & $7.8 \mathrm{a}$ & $5.3 \mathrm{a}$ & $2.8 \mathrm{a}$ \\
\hline Uovo di Piccione & 6.9 & 4.5 & $0.6 \mathrm{~b}$ & $7.1 \mathrm{ab}$ & $5.6 \mathrm{ab}$ & $0.9 \mathrm{~b}$ & $7.5 \mathrm{a}$ & $5.1 \mathrm{a}$ & $0.9 \mathrm{~b}$ \\
\hline \multicolumn{10}{|l|}{ Stratification treatment } \\
\hline $\mathrm{C}$ & $6.7 \mathrm{ab}^{\mathrm{z}}$ & 3.6 & 1.2 & 7.0 & 5.4 & 1.4 & 6.8 & $4.5 \mathrm{~b}$ & 1.3 \\
\hline $\mathrm{T} 1$ & $7.6 \mathrm{a}$ & 4.3 & 1.1 & 7.3 & 6.0 & 1.5 & 7.5 & $5.2 \mathrm{a}$ & 1.3 \\
\hline $\mathrm{T} 2$ & $5.3 \mathrm{~b}$ & 3.7 & 0.4 & 7.8 & 5.4 & 1.0 & & & \\
\hline \multicolumn{10}{|l|}{ Year } \\
\hline 2008 & & & & & & & 7.2 & $4.0 \mathrm{~b}$ & 1.2 \\
\hline 2009 & & & & & & & 7.2 & $5.7 \mathrm{a}$ & 1.4 \\
\hline $\mathrm{CV}(\%)^{\mathrm{y}}$ & 22.8 & 22.5 & 93.1 & 19.6 & 18.3 & 60.5 & 17.0 & 14.5 & 68.4 \\
\hline \multicolumn{10}{|l|}{ Significance } \\
\hline Cultivar & NS & NS & $*$ & $* *$ & $*$ & $* * *$ & $*$ & $* * *$ & $* *$ \\
\hline Stratification & $* *$ & NS & NS & NS & NS & NS & NS & $* *$ & NS \\
\hline Year & & & & & & & NS & $* * *$ & NS \\
\hline Cultivar * stratification & NS & NS & NS & NS & NS & NS & NS & NS & NS \\
\hline Year $*$ cultivar & & & & & & & NS & NS & NS \\
\hline Year * stratification & & & & & & & NS & NS & NS \\
\hline
\end{tabular}

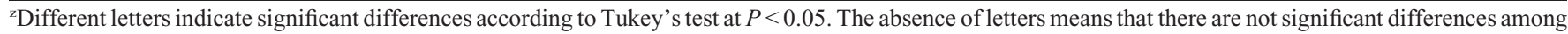
parameters.

${ }^{\mathrm{y}}$ Calculated among the whole data.

$\mathrm{C}=$ control, stratification for $30 \mathrm{~d}$ at $14{ }^{\circ} \mathrm{C}$; $\mathrm{T} 1=$ stratification for $18 \mathrm{~d}$ at $14{ }^{\circ} \mathrm{C}$ and $12 \mathrm{~d}$ at $25^{\circ} \mathrm{C} ; \mathrm{T} 2=$ stratification for $14 \mathrm{~d}$ at $14{ }^{\circ} \mathrm{C}$ and $7 \mathrm{~d}$ at $25^{\circ} \mathrm{C}$ in 2008 and stratification for $18 \mathrm{~d}$ at $14{ }^{\circ} \mathrm{C}$ and $7 \mathrm{~d}$ at $25^{\circ} \mathrm{C}$ in 2009 .

NS, *** and *** indicate nonsignificant and significant differences at $P<0.05,0.01$, or 0.001 , respectively. 


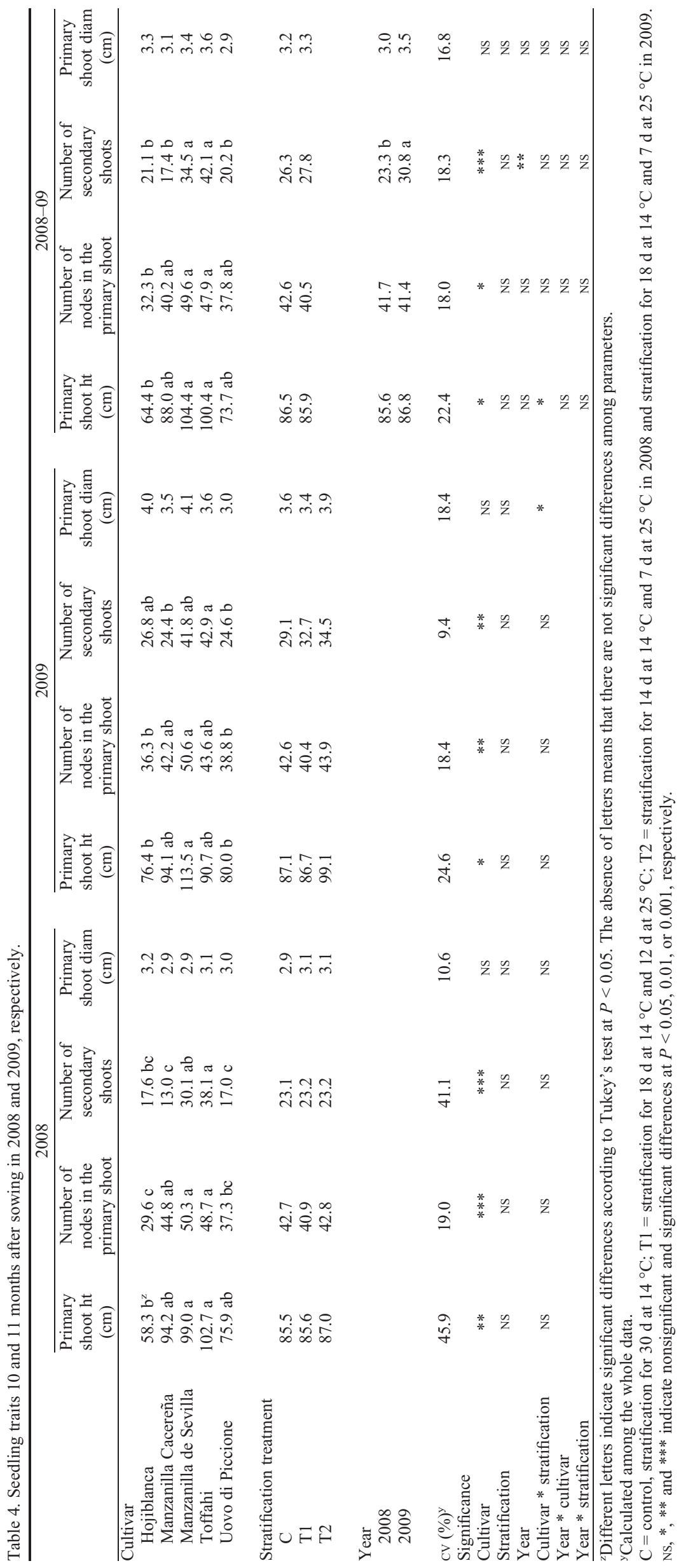

among seed germination, seedling emergence, and seedling growth traits (data not shown). Only a few interesting correlations were found, although in most cases, the coefficients were not high. In general, higher germination rates before sowing are correlated to higher seedling emergence $(0.88, P<$ $0.001)$. The radicle length before sowing may decrease the average time of seed germination $(-0.38, P<0.001)$, although no relationship is found between this parameter and seedling emergence. Therefore, an excessive seed development during stratification (mostly found in heat after chill treatments) is not necessary to obtain a higher number of emerged plants. In fact, manipulation of seeds with long radicles has been difficult during the trials.

Considering seedling growth parameters, the shoot heights at one and 10 or 11 months after sowing were not correlated. Nevertheless, a relationship was found between the number of secondary shoots at one and 10 or 11 months after sowing $(0.45, P<0.001)$, which suggests that the lower apical dominance of the seedlings shows up in the very early stages. A relationship was also found between the primary shoot height at 10 or 11 months after sowing and the diameter $(0.46$, $P<0.001)$, although not as strongly as indicated by Rallo et al. (2008) and Hammami et al. (2011) for olive seedlings at nine to 15 months $(0.88, P<0.001$ and $0.84, P<$ 0.05 , respectively). The taller shoots also had higher numbers of nodes than the smaller ones $(0.93, P<0.01)$.

In conclusion, the obtained results show that both the stratification treatment and the female parent clearly influenced olive seed germination and seedling emergence. Early seedling growth is also affected by the female parent. The standard stratification procedure used in olive breeding programs in Spain $\left(30 \mathrm{~d}\right.$ at $\left.14{ }^{\circ} \mathrm{C}\right)$ is still the most adequate, regardless of the studied female parent. A decrease in the number of days at $14^{\circ} \mathrm{C}$ below 18 seems to limit the ability to eliminate seed dormancy, although an increase in temperature from 14 to $25^{\circ} \mathrm{C}$ after this period of time may improve the radicle length and even reduce the average time of seedling emergence. Some cultivars have shown great variability with respect to the stratification requirements of the seeds. 'Hojiblanca' and 'Uovo di Piccione' probably require longer stratification periods to eliminate seed dormancy. Other cultivars such as Manzanilla de Sevilla and Toffahi seem to be a good choice to improve emergence rates and to obtain early vigorous progenies and, thus, shorter juvenile-period plants. The apical dominance habit is observed in the earlier stages of seedling development. The results also indicate the influence of the female parents on the number of fruits with empty seeds and fruits with double seeds. These should be considered to obtain the desirable seed samples in an olive breeding program, particularly if the mean temperature during flowering and fruit set is higher compared with the average mean values. 
Table 5. Relative percentage of discarded seedlings per female progenitor according to vigor screening proposed by Rallo et al. (2008) (40\% of the shortest plants are eliminated).

\begin{tabular}{lccc}
\hline & 2008 & 2009 & $2008-0$ \\
\hline Cultivar & & & \\
$\quad$ Hojiblanca & $71.4 \mathrm{a}^{\mathrm{z}}$ & 60.5 & $70.3 \mathrm{a}$ \\
Manzanilla Cacereña & $33.9 \mathrm{ab}$ & 44.6 & $47.8 \mathrm{ab}$ \\
Manzanilla de Sevilla & $36.4 \mathrm{ab}$ & 27.2 & $33.7 \mathrm{~b}$ \\
Toffahi & $27.2 \mathrm{~b}$ & 42.2 & $32.6 \mathrm{~b}$ \\
$\quad$ Uovo di Piccione & $61.8 \mathrm{a}$ & 50.4 & $64.3 \mathrm{a}$ \\
& & & \\
Stratification treatment & & & \\
$\quad$ C & 50.7 & 47.4 & 49.0 \\
T1 & 49.2 & 50.9 & 50.6 \\
T2 & 38.5 & 36.6 & \\
& & & \\
Year & & & 50.0 \\
$\quad 2008$ & & & 50.0 \\
2009 & & & \\
& 26.1 & 39.5 & 29.0 \\
CV (\%) & & & \\
Significance & $* *$ & NS & $* * *$ \\
Cultivar & NS & NS & NS \\
Stratification & & & NS \\
Year & NS & NS & NS \\
Cultivar * stratification & & & NS \\
Year * cultivar & & & NS \\
Year * stratification & &
\end{tabular}

${ }^{\mathrm{z}}$ Different letters indicate significant differences according to Tukey's test at $P<0.05$. The absence of letters means that there are not significant differences among parameters.

${ }^{y}$ Calculated among the whole data.

$\mathrm{C}=$ control, stratification for $30 \mathrm{~d}$ at $14{ }^{\circ} \mathrm{C} ; \mathrm{T} 1=$ stratification for $18 \mathrm{~d}$ at $14{ }^{\circ} \mathrm{C}$ and $12 \mathrm{~d}$ at $25^{\circ} \mathrm{C}$; $\mathrm{T} 2=$ stratification for $14 \mathrm{~d}$ at $14{ }^{\circ} \mathrm{C}$ and $7 \mathrm{~d}$ at $25^{\circ} \mathrm{C}$ in 2008 and stratification for $18 \mathrm{~d}$ at $14{ }^{\circ} \mathrm{C}$ and $7 \mathrm{~d}$ at $25^{\circ} \mathrm{C}$ in 2009 .

$\mathrm{NS}, * *$ and $* * *$ indicate nonsignificant and significant differences at $P<0.01$ or 0.001 , respectively.

\section{Literature Cited}

Adakalic, M. 2003. Técnicas de germinación y forzado de plántulas de olivo. MS thesis, Univ. of. Córdoba, Córdoba, Spain.

Adakalic, M., D. Barranco, L. León, and R. De la Rosa. 2008. Influence of harvest date on the germination and emergency of seeds of five olive cultivars. Acta Hort. 791:187-189.

Alvarado, J.A. 1994. Métodos para la germinación y crecimiento forzado de plántulas de olivo.
Trabajo profesional fin de carrera. ETSIAM. Univ. of Córdoba, Córdoba, Spain.

Beltrán, G., M. Uceda, M. Hermoso, and L. Frías. 2008. Maduración, p. 165-187. In: Barranco, D., R. Fernández-Escobar, and L. Rallo (eds.). El cultivo del olivo. Mundiprensa, Junta de Andalucía, Madrid, Spain.

Bini, G. and E. Benilli. 1975. Influenza dei genitori sulla facolta germinativa dei semi. Ricerche su'll olivo. Rivista Della Ortoflorofrutticoltura Italiana 59:371-384.

Box, G.E.P. and D.R. Cox. 1964. An analysis of transformations. J. R. Stat. Soc. B 26:211-252.

Bradley, M.V., W.H. Griggs, and H.T. Hartmann. 1961. Studies on self- and cross-pollination of olives under varying temperature conditions. Calif. Agr. 15:4-5.

Crisosto, C. and E.G. Sutter. 1985. Role of the endocarp in 'Manzanillo' olive seed germination. J. Amer. Soc. Hort. Sci. 110:50-52.

Cuevas, J. and R. Oller. 2002. Olive seed set and its impact on seed and fruit weight. Acta Hort. 586:485-488.

De la Rosa, R., A.I. Kiran, D. Barranco, and L. León. 2006. Seedling vigour as a preselection criterion for short juvenile period in olive breeding. Aust. J. Agr. Res. 57:477-481.

Edmond, J.B. and W.J. Drappala. 1958. The effect of temperature, sand and soil, and acetone on oka seed. P. Amer. Soc. Hort. Sci. 71:428-434

El Ryachi, M. 2007. Técnicas de propagación y de acortamiento del periodo juvenil en el programa de mejora del olivo. MS thesis, Univ. of Córdoba, Córdoba, Spain.

Farinelli, D., A. Tombesi, and D. Asan. 2008 Paternal and maternal effects on seed characteristics of olive cultivars. Acta Hort. 791:121-125.

García-Gusano, M., P. Martínez-Gómez, and F. Dicenta. 2004. Breaking dormancy in almond [Prunus dulcis (Mill.) D.A. Webb]. Sci. Hort. 99:363-370.

Gniazdowska, A., U. Krasuska, K. Czajkowska, and R. Bogatek. 2010. Nitric oxide, hydrogen cyanide and ethylene are required in the control of germination and undisturbed development of young apple seedlings. Plant Growth Regulat. 61:75-84.

Grigorian, V. 1972. L'embriogenèse chez l'Armandier (Prunus amygdalus Batsch) étude comparéde la dormance des graines et de la dormance des bourgerons végétatifs. PhD diss., Univ. of Bordeaux, Bordeaux, France.

Hammami, S.B.M., L. León, H. Rapoport, and R. De la Rosa. 2011. Early growth habit and vigour parameters in olive seedlings. Sci. Hort. $129: 761-768$
Hartmann, H.T., D.E. Kester, Jr., F.T. Davies, and L.R. Geneve. 2010. Plant propagation. Principles and practices. 8th Ed. Part II. Seed propagation. Prentice Hall, NJ.

Istanbouli, A. 1981. La multiplication sexuelle de l'olivier (Olea europaea L.) mise au point d'une technique de reproduction rapide de jeunes plantes issues de semis. Atti. Sem. Intl. Cult. Intens. Oliv. Marrakech. 55-72.

Lagarda, A., G.C. Martin, and D.E. Kester. 1983. Influence of environment, seed tissue, and seed maturity on 'Manzanillo' olive seed germination. HortScience 18:868-869.

Martínez-Gómez, P. and F. Dicenta. 2001. Mechanisms of dormancy in seeds of peach [Prunus persica (L.) Batsch] cv. GF 305. Sci. Hort. 91:51-58.

Orlandi, F., F. Ferranti, B. Romano, and M. Fornaciari. 2003. Olive pollination: Flowers and pollen of two cultivars of Olea europaea. N.Z. J. Crop Hort. 31:159-168.

Pritsa, T.S., D.G. Voyiatzis, C.J. Voyiatzis, and M.S. Sotitiriou. 2003. Evaluation of vegetative traits and their relation to time to first flowering of olive seedlings. Aust. J. Agr. Res. 54:371-376.

Rallo, P., R. Jiménez, J. Ordovás, and M.P. Suárez. 2008. Possible early selection of short juvenile period olive plants based on seedling traits. Aust. J. Agr. Res. 59:933-940.

Santos-Antunes, F. 1999. Acortamiento del periodo juvenil en olivo mediante técnicas de forzado de crecimiento y elección de genitores. PhD thesis, Univ. of Córdoba, Córdoba, Spain.

Santos-Antunes, F., L. León, R. De la Rosa, J. Alvarado, A. Mohedo, I. Trujillo, and L. Rallo. 2005. The length of the juvenile period in olive as influence by vigor of the seedlings and the precocity of the parents. HortScience 40:12131215.

Sharma, H.C. and R.N. Singh. 1978. Effect of stratification-temperature, chemical treatments and seed coat on the growth of peach seedlings cultivar 'Sharbati'. Sci. Hort. 9:259-263.

Sotomayor-León, E.M. and J.M. Caballero. 1990. An easy method of breaking olive stones to remove mechanical dormancy. Acta Hort. 286: 113-116.

Voyiatzis, D.G. 1995. Dormancy and germination of olive embryos as affected by temperature. Physiol. Plant. 95:444-448.

Voyiatzis, D.G. and I.D. Porlingis. 1987. Temperature requirements for the germination of olive seeds (Olea europaea L.). J. Hort. Sci. 62:405411. 